\title{
COMMUNITY SERVICE IN STUDY POTENTIAL TECHNOLOGY OF EDUCATION TOUR AND BUSINESS PROSPECTS OF TRADERS IN TULUNGAGUNG
}

\author{
Sri Wahyuni Mega Hastuti ${ }^{*}$, Wawan Herry Setyawan ${ }^{2 *}$ \\ 1,2 Universitas Islam Kadiri, Kediri, Indonesia \\ *Penulis Koresponsensi, email: wawansetyawan@uniska-kediri.ac.id
}

\begin{abstract}
The purpose of this study is to identify the potential for educational tourism, training facility and business prospects that can be developed by street vendors in Tulungagung Regency, analyze the obstacles faced by each street vendor area, determine the potential for educational tourism and business prospects for street vendors in each area in Tulungagung district. The research location is in 5 street vendors in Tulungagung district. This type of research is descriptive, namely in-depth analysis of the data that has been collected. The results showed that the street vendors's Redjoagung Business Area have the potential to be developed and have prospects because they are strategically located on the side of the provincial road in the Stadium area and the Sports Building so that it is possible to become a Rest Area. PKL Pujasera Ngemplak has potential and prospects for development because it is close to traditional markets, fruit markets and chicken markets, so that day and night there are many buyers and training facilities. PKL Kali Ngrowo Water Front area has the potential to be developed and has prospects because it is in a river tourism area which is currently the focus of educational tourism development by the local government of Tulungagung district. The street vendors's Pasar Senggol area have the potential to be developed and have prospects because they have a unique culinary center for food in the past, strategically located, becoming the destination for visitors who exercise in the morning. The street vendors's Popoh Beach area have the potential to be developed and have prospects along with the improvement of Popoh Beach tourism facilities, moreover, the government's attention is quite big on the development of tourist areas and currently the Southern Cross Route is being built.
\end{abstract}

Keywords: Education tour, Business prospects of traders'street vendor

\begin{abstract}
Abstrak. Tujuan kajian ini mengidentifikasi potensi wisata edukasi serta fasilitas pelatihan dan prospek bisnis yang bisa dikembangkan pedagang kaki lima yang ada di Kabupaten Tulungagung, menganalisis kendala yang dihadapi masing-masing kawasan PKL, mengetahui potensi wisata edukasi dan prospek bisnis PKL di masing masing kawasan di kabupaten Tulungagung. Lokasi penelitian adalah di 5 kawasan PKL di kabupaten Tulungagung. Jenis penelitian ini adalah Diskriptif yaitu analisa mendalam dari data-data yang berhasil dikumpulkan. Hasil penelitian menunjukkan bahwa PKL di Kawasan Usaha PKL Redjoagung memiliki potensi untuk dikembangkan dan berprospek karena berlokasi strategis di pinggir jalan Provinsi di area Stadiun dan Gedung Olahraga sehingga memungkinkan untuk dijadikan Rest Area. PKL Kawasan Usaha PKL Pujasera Ngemplak, berpotensi dan berprospek pengembangandan dikarenakan berdekatan dengan Pasar tradisional, pasar buah dan pasar ayam, sehingga siang dan malam ramai pembeli dan fasilitas pelatihan. PKL kawasan Kali Ngrowo Water Front berpotensi dikembangkan dan berprospek karena berada pada kawasan wisata sungai yang saat ini menjadi fokus pembangunan wisata pendidikan oleh pemerintah daerah kabupaten Tulungagung. PKL kawasan Pasar Senggol berpotensi untuk dikembangkan dan berprospek karena memiliki keunikan sentra kuliner makanan tempo dulu, berlokasi strategid, menjadi tujuan pengunjung yang berolahraga pagi. PKL kawasan Pantai Popoh, berpotensi dikembangkan dan berprospek seiring dengan perbaikan sarana wisata Pantai Popoh, terlebih lagi perhatian pemerintah cukup besar terhadap pembangunan kawasan wisata dan saat ini tengah dibangun Jalur Lintas Selatan.
\end{abstract}

Kata Kunci: Wisata Edukasi, Prospek bisnis pedagang kaki lima

How to Cite: Hastuti, S. W. M. \& Setyawan,W.H. (2021). Community Service in Study Potential Technology of Education Tour and Business Prospects of Traders in Tulungagung. Mitra Mahajana: Jurnal Pengabdian Masyarakat, 2(2), 134-144. https://doi.org/10.37478/mahajana.v2i2.952

\section{INTRODUCTION}

Technology development has been used to support all aspects of fulfilling human needs and desires. Today the use of technology is the basis for the modern business management paradigm. Saptaria \& Setyawan (2021) said that Entrepreneurs are competing to build digital businesses to be able to increase competitiveness and efficiency of science and technologybased business processes. technology can be utilized for the tourism sector. Tourism is a sector that contributes significantly to Gross Domestic Product. 
Currently tourism has grown very rapidly in recent years. Tourism can encourage economic activity in areas where tourism is developed and at the same time can encourage economic activity around it. Street vendors or abbreviated as PKL is a term to refer to merchants who use carts. Collaboration between technologiy in tourism tour and PKL can make people confortable there (Harianto et al., 2020). The term is often interpreted this way because there are five legs of the merchant. The five legs are the two feet of the merchant plus the three "legs" of the cart (which are actually three wheels or two wheels and one leg). Street vendors have the same meaning as 'hawkers', which are defined as people who offer goods and services for sale in public places, especially on roadsides and sidewalks (Rustijadji, 2019). Tourism is a sector that contributes significantly to Gross Domestic Product. currently tourism has grown very rapidly in recent years. Tourism can encourage economic activity in areas where tourism is developed and at the same time can encourage economic activity around it. Street vendors or abbreviated as PKL is a term to refer to merchants who use carts. The term is often interpreted this way because there are five legs of the merchant. The five legs are the two feet of the merchant plus the three "legs" of the cart (which are actually three wheels or two wheels and one leg). Street vendors have the same meaning as 'hawkers', which are defined as people who offer goods and services for sale in public places, especially on roadsides and sidewalks (Permadi, 2007).

PKL activities are strongly influenced by formal sector activities in attracting consumers. The location of street vendors is strongly influenced by direct and indirect relationships with various formal and informal activities or the relationship between street vendors and their consumers (Utami, 2014). The existence of street vendors is the impact of the difficulty of the community's economy, the number of workers is increasing, which is not equal to the available jobs, resulting in an increase in the number of unemployed (Hadi, 2019).

The problem of street vendors occupying the sides of the road greatly disrupts traffic and disrupts the road infrastructure causing chaos and congestion in the city, creating a dirty and unhealthy environment. Street vendors occupying public spaces and roads can also create social problems such as the presence of pickpockets, thieves, and so on (Larasati \& Pamungkas, 2016). Street vendors are seen as illegal activities and sometimes treated like criminals. Studies show that in almost all Asian countries, street vendors do not have a legal status to run their business. PKL is seen as a non-profit activity, because it does not contribute to the local or national economy through taxes (Nurcahyani et al., 2020). They are marginalized in the development agenda, so they are adversely affected by macro-socio-economic policies.

On the positive side, for some community groups, street vendors are actually a solution, because they provide cheaper prices. PKL as part of the informal sector business has the potential to create and expand employment for people who lack adequate skills and expertise due to low levels of education. They are tenacious workers, struggling to support their families (Sinollah, 2018).

The Central Government has issued Presidential Regulation No. 125/2012 concerning the Coordination of Structuring and Empowerment of Street Traders, then followed up by the issuance of Minister of Home Affairs Regulation No. 41/2012 concerning Guidelines for Structuring and Empowering Street Vendors. In the regulation, it is stated that the purpose of structuring and empowering street vendors (PKL) is to provide business opportunities for street vendors by determining the location according to their designation; grow and develop the ability of street vendors to become strong and independent micro-economic enterprises; and to create a city that is clean, beautiful, orderly and safe with adequate and environmentally sound urban facilities and infrastructure (Indonesia, 2012). Therefore, the Provincial Government and City / Regency Government are required to organize and develop PKL in their respective areas.

The Regent / Mayor is also required to empower street vendors by increasing their business capacity; facilitation of access to capital; facilitation of trade facilities assistance; 
institutional strengthening; facilitation of increased production; processing, network development and promotion; and technical guidance and guidance (Soeprajitno et al., 2019a).

The use of technology in business is the activity of practical application of science to the industrial world or as a knowledge framework used to create tools, to develop expertise and extract material to solve problems in society. (Setyawan et al., 2019). The ability to produce appropriate technology products and new technology-based services is an important job for educational tourism (Rifai et al., 2020).

One of the strategies to achieve this goal is to provide space and technology as an attraction to be used in entrepreneurship and education (Setyawan et al., 2018). the tourism sector uses technology in the form of posters, advertisements with social media technology about tourism as a learning tool for visitors. Based on the situation analysis above, it is necessary to conduct a study to determine the typology, obstacles faced, the potential and prospects of each street vendor area to support the development of tourism in Tulungagung Regency.

The purpose of implementing this PKM is to help the Tulungagung Regency government to analyze: (1) how is the typology of each street vendor area as educational tour in Tulungagung Regency, (2) what are the obstacles faced by each productive street vendor area in Tulungagung district, (3) how potential for street vendors and educational tours of each area are in Tulungagung district, (4) What are the prospects for street vendors in each area to support education tour.

\section{IMPLEMENTATION METHODS}

Community Service Activities are one of the study stages for the development of street vendors in Tulungagung Regency (Budiman \& Samani, 2021). The implementation of this study uses a descriptive research approach based on filling out a questionnaire presented in the form of a percentage table as a basis for analyzing the business prospects of street vendors and educational tourism in Tulungagung Regency. This research was conducted in 5 (five) street vendors in Tulungagung district. Extracting primary and secondary data. Primary data were obtained by conducting direct interviews with street vendors in Tulungagung district and distributing questionnaires and completing primary data required observation by directly observing trading business activities. Apart from primary data, secondary data is also needed which can be obtained from relevant research reports, which can also be obtained from various documentation at the Office of Cooperatives and Micro Enterprises of Tulungagung Regency.

This research is classified as a survey research, meaning that all street vendors become research respondents (Setyawan et al., 2018). The instrument used for extracting this information is a list of relevant questions (questionnaires) that must be answered by respondents (PKL). If the respondent has difficulty filling it out, the surveyor must use other methods such as interviews and / or observation and write down the results in a questionnaire.

The population in this study were street vendors in Tulungagung district. The population criteria are: a) street vendors and education tour located in a certain area, b) the number in one area is at least 30 traders, c) trading continuously, d) trading period of at least 1 (one) year. Based on the population criteria, 5 (five) street vendors with training facilities were found in Tulungagung district. The PKL areas that were the research respondents were as follows:

1. Education Tour and Redjoagung PKL Business Area, there are 32 traders. Redjoagung Village, Kedungwaru District, Tulungagung Regency

2. Education Tour and Business Area PKL Pujasera Ngemplak, as many as 31 traders. Jl. Abdul Fatah, Botoran Village, Tulungagung City District, Tulungagung Regency

3. Education Tour and Kali Ngrowo Waterfront PKL Business Area, as many as 32 traders. Jl. West Patimura, Boyolangu District, Tulungagung Regency 
4. Education Tour and Senggol Market PKL Business Area, there are 42 traders. Bagoan Village, Kedungwaru District, Tulungagung Regency

5. Education Tour and Pantai Popoh street vendors, as many as 53 traders. Besole Village, Besuki District, Tulungagung Regency.

\section{RESULTS AND DISCUSSION}

Research activities were carried out in August-December 2020. Based on the population criteria, there are 5 (five) street vendors in Tulungagung district. Widyaningrum (2009) she found that the informal economic activities of the city, especially the street vendors, are a complex problem. To support this research, it was found that the street vendor's problem needed a solution to organize it.

Table 1. Education Tour and PKL Redjoagung, Tulungagung

\begin{tabular}{lll}
\hline PROFILE PKL & QUANTITY & INFORMATION \\
\hline 1. Institutional & \multicolumn{1}{c}{ Field Area } & Redjoagung, \\
Place of business & $\begin{array}{l}\text { Tulungagung } \\
\text { Number of street vendors }\end{array}$ & \\
Legality & $: 31$ Person & \\
Type of Trade & $:$ Not available & Traditional toys $(10 \%)$ \\
Length of effort & $:$ Food Drink & $>10$ Years : $25 \%$ \\
2. Human Resources & $:<10$ Years : $75 \%$ & \\
Total manpower & $: 1-3$ Person & \\
3. Marketing & & \\
Market segment & $:$ All people & \\
Omzet & $:>1$ million : $60 \%$ & \\
Promotion type & $:$ Banner, website & \\
4. Finance & & \\
Capital Resources & $:$ Owner's equity : $80 \%$ & credit: $20 \%$ \\
Big Capital & $:<5$ million : $20 \%$ & 5 sd 10 million : $80 \%$ \\
Financial records & $:$ Not systematic yet & \\
5. Facilitating Development & & \\
Training & $: 20 \%$ & - Training help other \\
Help Means & $: 70 \%$ & - Facilities to help others \\
Has not received facilitation & $: 10 \%$ & \\
\hline Source: & \\
\hline
\end{tabular}

Source: Monev Instrument for Learning Devices (Data processed)

\section{A. Business Potential Analysis}

There are facilities to educate people how to handle Tsunami and earthquake, including knowledge, skills, experience, mental skills that can be developed so that they can be better are:

a. Technology of short movie and entertainment have to complete the facility. The number of traders is quite large and has the potential to become a business center in an area.

b. Has been established for more than 10 years, is the capital of business experience

c. This type of food and beverage trade is a commodity that consumers always need every day.

d. No big capital is needed to exist (Soeprajitno et al., 2019b).

e. Receive local government support of facilities and business premises.

\section{B. Business Prospect Analysis}

The prospect of developing a street vendor business in the Redjoagung field in 
Tulungagung has good prospects for the following reasons:

a. Being in a Sports stadium Redjoagung sports stadium, besides being used for football fields, can also be used for atlantic sports such as running. Training help other.

b. There is a Tenes field gym

c. There is a Badminton building

d. Close to schools, Police stations, Heroes Cemetery and Penitentiary

e. Provincial roadside

f. Facilities to help others as education turism, flying fox, coloring area facilities for children, etc.

Table 2. Education tour and PKL Ngemplak Pujasera Area, Tulungagung

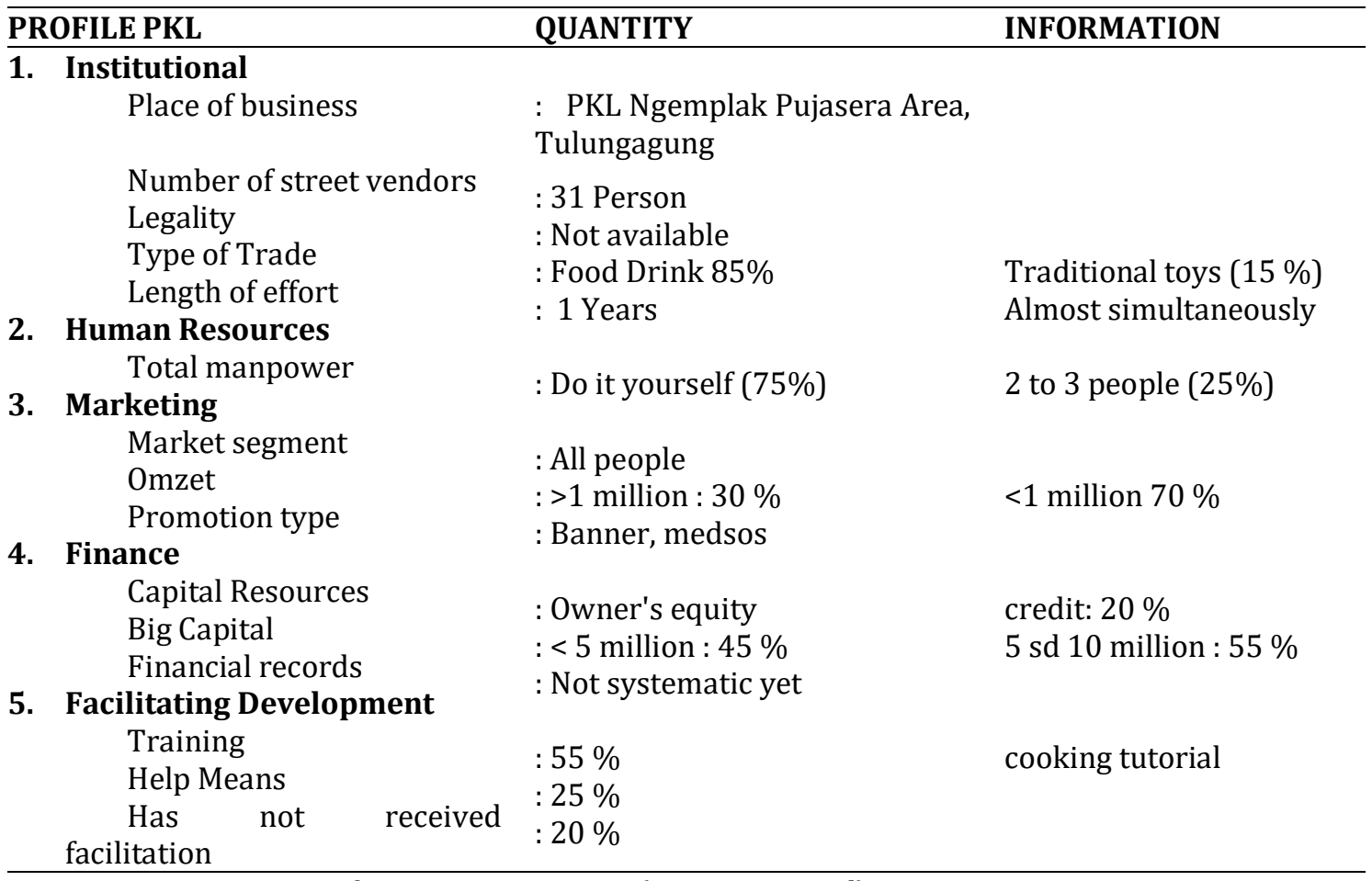

Source: Monev Instrument for Learning Devices (Data processed)

\section{A. Business Potential Analysis}

Resources or potential of Pujasera Ngemplak Tulungagung street vendors that can be developed are as follows:

a. Provide member training and educate people to produce home production in named "Koperasi MUMPUNI". The location of this street vendor is in a crowded area. because it is near the market, and focus of development in the Tulungagung area.

b. The gathering of as many as 31 traders is enough to attract consumers to stop by.

c. A street vendor association has been formed and there is a Ngemplak Pujasera PKL Cooperative

d. Increasing human resources and facilities supported by the Government.

\section{B. Business Prospect Analysis}

PKL Pujasera Ngemplak, has a pretty good business development prospect and tourisms 
have contributed cooking tutorial on the grounds that it has a busy location. the place is adjacent to the market. The prospect is a place to quench the thirst / hunger of buyers and market traders. This street vendor is always crowded with buyers., Adjacent to the market which is open all day. The fruit market is located beside this street vendor area which is also open at night so that it is always busy all day and night.

Table 3. Education Tour and Street vendors at Kali Ngrowo Water Front, Boyolangu

\begin{tabular}{|c|c|c|c|}
\hline \multicolumn{2}{|r|}{ PROFILE PKL } & \multirow[t]{2}{*}{ QUANTITY } & \multirow[t]{2}{*}{ INFORMATION } \\
\hline \multirow[t]{5}{*}{1.} & Institutional & & \\
\hline & Place of business & $\begin{array}{l}\text { : PKL at Kali Ngrowo Water } \\
\text { Front, Boyolangu }\end{array}$ & \\
\hline & Number of street vendors & : 32 active traders every day & \\
\hline & Legality & : Not available & \\
\hline & Type of Trade & : Food Drink 90\% & Traditional toys (10\%) \\
\hline \multirow{2}{*}{2.} & $\begin{array}{l}\text { Length of effort } \\
\text { Human Resources }\end{array}$ & $:>5$ Years & Almost simultaneously \\
\hline & Total manpower & : Do it yourself $(80 \%)$ & 2 to 3 people $(20 \%)$ \\
\hline \multirow[t]{3}{*}{3.} & Marketing & : Youth & Can all people \\
\hline & Market segment & : >1 million : $20 \%$ & $<1$ million $80 \%$ \\
\hline & $\begin{array}{l}\text { Omzet } \\
\text { Promotion type }\end{array}$ & :Banner, media radio & \\
\hline \multirow[t]{4}{*}{4.} & Finance & - Owner's equity & credit. $20 \%$ \\
\hline & Capital Resources & $:<5$ million : $40 \%$ & 5 sd 10 million : $60 \%$ \\
\hline & Big Capital & : Not systematic yet & \\
\hline & Financial records & & \\
\hline \multirow[t]{4}{*}{5.} & Facilitating Development & & \\
\hline & Training & : $30 \%$ & it supports as a \\
\hline & Help Means & $: 40 \%$ & regional education \\
\hline & Has not received facilitation & $: 20 \%$ & tourist destination \\
\hline
\end{tabular}

\section{A. Business Potential Analysis}

Potential or resources owned by PKL in the Kali Ngrowo Water Front Area Boyolangu, Tulungagung that can be developed are as follows:

a. Along the river at the Ngrowo Water Front river, there are about 32 traders open every day, others open on busy days.

b. The commodities that are sold are contemporary foods and drinks that are loved by teenagers.

c. The capital needed is relatively not much so that it allows the entry of new competitors who also enliven the culinary

d. The government supports it as a regional education tourist destination

\section{B. Business Prospect Analysis}

Business prospects for street vendors in the Kali Ngrowo Water Front Boyolangu area, Tulungagung, can be said to have the prospect of being developed. The reason is prospective because the PKL Water Front area is located on the edge of the main Tulungagung river flow where the environment has been arranged in such a way that it is attractive as a cheap recreation place for all groups, especially teenagers, who like to spend their nights in this area while breathing the cool riverbank air. There is training for tourism and athletic swimming in this area. 
Table 4. Education Tour and PKL Market Senggol, Tulungagung

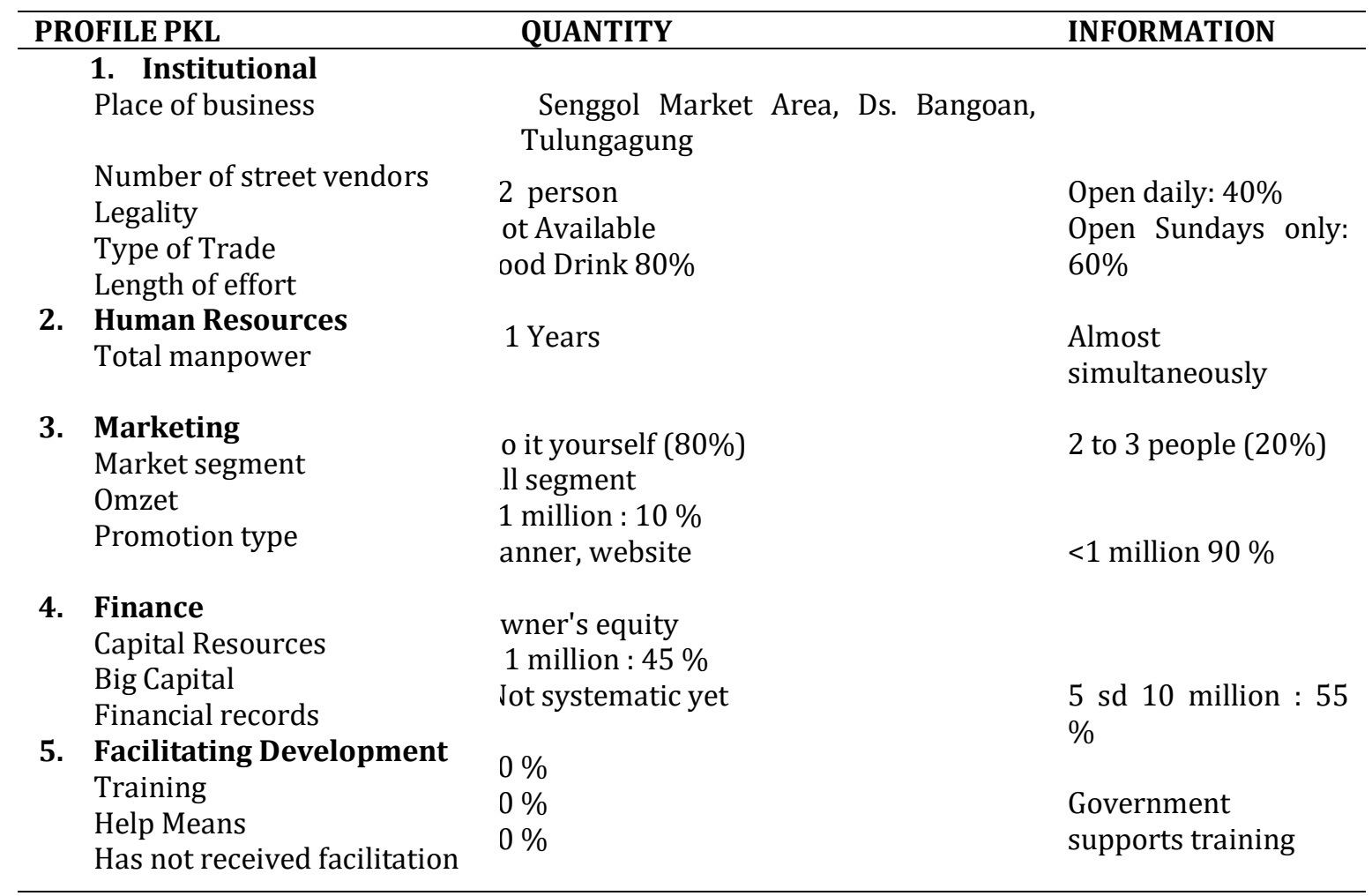

Source: Monev Instrument for Learning Devices (Data processed)

\section{A. Business Potential Analysis}

PKL Pasar Senggol, Bangoan Tulungagung ds has the following potentials that can be developed:

a. There are English training and 42 merchants selling in one place, attracting consumers to come.

b. The PKL Pasar Senggol business area is located in a rural area with cool air, adjacent to rice fields, a position in a corner, so it is interesting to visit.

c. The commodities that are sold are unique, namely traditional food and drinks, so if consumers miss food and drinks in the past, they will come to the Senggol Market street vendor area.

d. Market facilities are supported by the government, although few have been trained.

\section{B. Business Potential Analysis}

PKL Pasar Senggol, Bangoan ds Tulungagung district, has a pretty good business development prospect if traders can sell every day. The existence of busy buyers only on Saturdays, which causes many buyers to be reluctant to sell every day. On Sundays and holidays, people are enthusiastic about exercising, taking a leisurely walk then taking a break at the market and enjoying old food and drinks. The location of the business is quite strategic, even though it is in the village, but this Senggol Market street vendor is located

Table 5. Education Tour and PKL Popoh Beach, Tulungagung

\begin{tabular}{lll}
\hline PROFILE PKL & QUANTITY & INFORMATION \\
\hline 1. & Institutional \\
& Place of business & $:$ PKL Pantai Popoh, Tulungagung
\end{tabular}




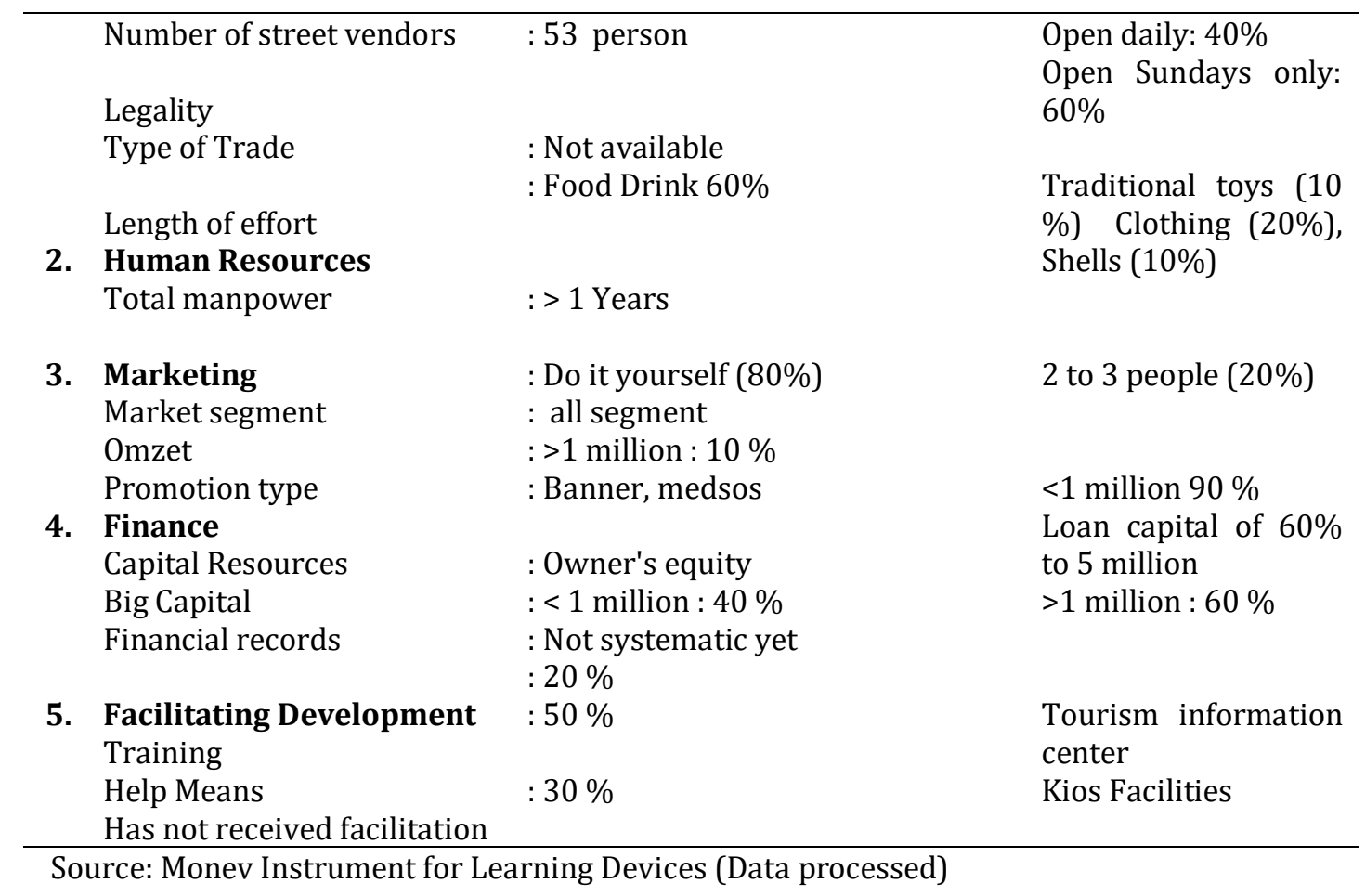

\section{A. Business Potential Analysis}

Business Potentials owned by street vendors in the beach area of Popoh Tulungagung are:
a. Tourism information center and the Street Traders Association has been formed with 53 traders as members.
b. Popoh Beach was once known for its beautiful beaches in East Java
c. The location of Popoh beach is easily accessible.
d. Grilled fish specialties attract visitors

\section{B. Business Prospect Analysis}

The condition of Popoh beach is currently experiencing a decline in the image of the community, where in the past Popoh beach was known as a beautiful beach, due to good management, cleanliness is not maintained, so tourists are reluctant to visit this beach. Meanwhile, when viewed from business prospects, Popoh beach still has good prospects. Currently, the JLS (Southern Cross Road) is being built, which is a road that connects areas in East Java via the southern route, with an extraordinary view. Popoh Beach must clean up and improve people's perceptions of opening up business opportunities in this area's arena. The development of tourist areas is synonymous with structuring, fostering street vendors as the end of tourists' interest in visiting tourist objects. Improving the conditions of street vendors means advancing the community's economy. So the existence of street vendors is closely related to the improvement of tourist areas.

\section{CONCLUSION AND RECOMENDATION}

1. Results of a Study on PKL Redjoagung Street Vendor Business Area resulted in information that there were Technology of short movie, entertainment and 31 identified traders, $90 \%$ of the types of food and beverage businesses, all of whom did not have a business entity, the majority of the workforce was managed independently, occupied an area provided by the government, the potential for educational tourism to be Competence of traders in processing food is still lacking, competence in managerial skills is still weak. This area has the potential to be developed because it is strategically 
located on the side of a provincial road in the Stadium and Sports Building area, making it possible to become a Rest Area.

2. Results of a Study on PKL Business Area PKL Pujasera Ngemplak, training and educating people produce home production. The results in information that there were 31 identified traders, all traders did not have legality, the majority of business types were food and beverage, managed by a maximum of 3 workers, there were varying competencies in managing the business. some traders have mastered delicious food management techniques but some have not, techniques to win the competition, carry out promotions and service techniques have been mastered by some traders. Turnover and business assets vary from small to large so that capital requirements vary. There is potential for the development of this street vendor business area because the Ngemplak Pujasera is close to traditional markets, fruit markets and chicken markets, so that day and night there are many buyers.

3. Results of a Study on Kali Ngrowo PKL business area, namely Water Front, obtained information that there supports as a regional education tourist destination and 32 identified traders, the majority of business types were food and beverage, did not have business legality, were managed independently by a maximum of 3 people, had not been able to provide large amounts of merchandise due to capital constraints. , food processing techniques are still weak, do not have excellent service techniques, promotion techniques and strategies to win the competition. This PKL area has the potential to be developed because it is located in a river educational tourism area which is currently the focus of tourism development by the Tulungagung district government.

4. Results of a Study on Senggol Market street vendor area were Government supports English training and 42 identified traders, the majority of business types were food and beverage, all of which did not have business legality, were managed by one to 3 people, minimal supplies of goods due to capital limitations, the majority opened businesses on Sundays morning, low turnover and business assets, expert traders in making traditional foods that are characteristic of the senggol market, managerial skills have not been mastered by traders so they cannot provide excellent service, techniques to win competition and have not applied promotional strategies. The PKL Pasar Senggol business area has the potential for educational tourism to be developed because it has a unique food culinary center in the past, is strategically located, a destination for visitors who have morning exercise.

5. Results of a Study on Pantai Popoh PKL business area resulted in information are tourism information center and 53 identified traders more than 10 years of business experience, varied types of business, providing tourists needs such as food, drinks, clothing, crafts, traders have been able to process various marine fish into The strength of street vendors in this area, the majority of turnover and assets are low due to complaints about the management of this tourism object so that tourists tend to decline, managerial skills have been controlled by some traders, but the condition of the tourist area has a sluggish impact on street vendors. The Popoh Beach PKL business area has the potential to be developed along with the improvement of Popoh Beach tourism facilities, moreover, the government's attention is quite big on the development of the tourist area and currently the Southern Cross Route is being built.

\section{REFERENCES}

Budiman, A., \& Samani, M. (2021). The Development of Direct-Contextual Learning: A New Model on Higher Education. International Journal of Higher Education, 10(2), 15-26. https://doi.org/doi:10.5430/ijhe.v10n2p15

Setyawan, W.H., Budiman, A., Sumarno, A., \& Rais, P. (2018). Challenged Solving in Listening Through T-Mobile Learning Model. International Journal of Engineering \& Technology, 
7(4.15), 443. https://doi.org/10.14419/ijet.v7i4.15.25253

Hadi, N. (2019). Transaksi Pedagang Asongan Menurut Ekonomi Syariah. Tribakti: Jurnal Pemikiran Keislaman, 30(2), 308-323. https://doi.org/https://doi.org/10.33367/tribakti.v30i2.815

Harianto, G. P., Rusijono, R., Masitoh, S., \& Setyawan, W. H. (2020). Collaborative-Cooperative Learning Model to Improve Theology Students'characters: Is it Effective? Jurnal Cakrawala Pendidikan, 39(2). https://doi.org/10.21831/cp.v39i2.31272

Indonesia, R. (2012). Peraturan Menteri Dalam Negeri Indonesia Nomor 41 Tahun 2012 Tentang Pedoman Penataan dan Pemberdayaan Pedagang Kaki Lima. Berita Negara Republik Indonesia Tahun.

Larasati, K. D., \& Pamungkas, A. (2016). Model Kerjasama Perencanaan Ruang dalam Menangani Akar Masalah Pedagang Kaki Lima di Kawasan Kaki Jembatan Suramadu Sisi Surabaya. Jurnal Teknik ITS, 4(2), C155-C160. https://doi.org/10.12962/j23373539.v4i2.11023

Nurcahyani, D., Sulton, S., \& Asmaroini, A. P. (2020). Perjuangan Pedagang Kaki Lima (PKL) dalam Membangun Identitas Kewargaan. Civic-Culture: Jurnal Ilmu Pendidikan PKN Dan Sosial Budaya, 4(2 Extra), 51-70. https://doi.org/10.31597/ccj.v4i2\%20Extra.445

Permadi, G. (2007). Pedagang kaki lima: riwayatmu dulu, nasibmu kini! Yudhistira Ghalia Indonesia.

https://books.google.co.id/books?hl=id\&lr=\&id=zUSKaV2GTDwC\&oi=fnd\&pg=PA16\&dq= Permadi,+G.+(2007).+Pedagang+kaki+lima:\&ots=Y1f94IIrzd\&sig=s_GbhBFoI1zWm09ggyc G_iRiZAk\&redir_esc=y\#v=onepage\&q=Permadi\%2C G. (2007). Pedagang kaki lima $\% 3 A \& f=$ false

Rifai, M., Masitoh, S., Bachri, B. S., Setyawan, W. H., Nurdyansyah, N., \& Puspitasari, H. (2020). Using Electronic Design Automation and Guided Inquiry Learning Model in Higher Engineering Education. Universal Journal of Educational Research. https://doi.org/10.13189/ujer.2020.080723

Rustijadji, R. B. L. (2019). Analisis dan perancangan sistem siklus pendapatan pada perusahaan dagang PT. Antari Jaya Mandiri. Widya Mandala Catholic University Surabaya.

Saptaria, L., \& Setyawan, W. H. (2021). DESAIN PEMBELAJARAN TECHNOPRENEURSHIP UNTUK MENINGKATKAN MOTIVASI BERWIRAUSAHA MAHASISWA UNISKA KEDIRI. Prima Magistra: Jurnal Ilmiah Kependidikan, 2(1), 77-89. https://doi.org/https://doi.org/10.37478/jpm.v2i1.880

Setyawan, W. H., Budiman, A., Wihara, D. S., Setyarini, T., Rahim, R., \& Wajdi, M. B. N. (2019). The effect of an android-based application on T-Mobile learning model to improve students' listening competence. Journal of Physics: Conference Series, 1175(1), 12217.

Setyawan, W., Rusijono, M., \& Jannah, M. (2018). T-Mobile Learning Android Model-Based to Improve Students' Listening Capability. 1st International Conference on Education Innovation (ICEI 2017). https://doi.org/10.2991/icei-17.2018.96

Sinollah, S. (2018). PEDAGANG KAKI LIMA SEBAGAI ALTERNATIF KESEMPATAN KERJA (Studi Kasus PKL di Pasar Lama dan Pasar Buah Kecamatan Pandaan Kabupaten Pasuruan). $\begin{array}{lll}\text { Jurnal Ekuivalensi, } & \text { 2(2), }\end{array}$ https://ejournal.kahuripan.ac.id/index.php/Ekuivalensi/article/view/34

Soeprajitno, E. D., Setyawan, W. H., \& Wihara, D. S. (2019a). Dampak Pelatihan "Service Excellence" Terhadap Kinerja Karyawan Bank Perkreditan Rakyat (Bpr) Kota Kediri. Jurnal MEBIS (Manajemen Dan Bisnis), 4(2), 94-102. https://doi.org/10.33005/mebis.v4i2.58

Soeprajitno, E. D., Setyawan, W. H., \& Wihara, D. S. (2019b). FAKTOR UTAMA YANG MEMPENGARUHI NASABAH DALAM MENGAMBIL KREDIT DI BANK PERKREDITAN 
RAKYAT (BPR) KOTA KEDIRI. CAPITAL: JURNAL EKONOMI DAN MANAJEMEN, 3(1), 48-59. http://doi.org/10.25273/capital.v3i1.5063

Utami, T. (2014). Pemberdayaan Komunitas Sektor Informal Pedagang Kaki Lima (Pkl), Suatual Ternatif Penanggulangan Kemiskinan. Jurnal Sosiologi DILEMA, 25(2). https://core.ac.uk/download/pdf/12345735.pdf

Widyaningrum, N. (2009). Kota Dan Pedagang Kaki Lima. Jurnal Analisis Sosial, 1-18. https://media.neliti.com/media/publications/535-ID-kota-dan-pedagang-kaki-lima.pdf 